Article

\title{
Electrochemical L-Lactic Acid Sensor Based on Immobilized ZnO Nanorods with Lactate Oxidase
}

\section{Zafar Hussain Ibupoto *, Syed Muhammad Usman Ali Shah, Kimleang Khun and Magnus Willander}

Department of Science and Technology, Campus Norrköping, Linköping University, SE-60174, Norrköping, Sweden; E-Mails: usman.ali@liu.se (S.M.U.A.S.); kimleang.khun@liu.se (K.K.); magnus.willander@liu.se (M.W.)

* Author to whom correspondence should be addressed; E-Mail: zafar.hussain.ibupoto@liu.se; Tel.: +46-0-11-363-119; Fax: +46-0-11-363-270.

Received: 28 December 2011; in revised form: 29 January 2012 / Accepted: 21 February 2012 / Published: 23 February 2012

\begin{abstract}
In this work, fabrication of gold coated glass substrate, growth of $\mathrm{ZnO}$ nanorods and potentiometric response of lactic acid are explained. The biosensor was developed by immobilizing the lactate oxidase on the $\mathrm{ZnO}$ nanorods in combination with glutaraldehyde as a cross linker for lactate oxidase enzyme. The potentiometric technique was applied for the measuring the output (EMF) response of L-lactic acid biosensor. We noticed that the present biosensor has wide linear detection range of concentration from $1 \times 10^{-4}-1 \times 10^{0} \mathrm{mM}$ with acceptable sensitivity about $41.33 \pm 1.58 \mathrm{mV} /$ decade. In addition, the proposed biosensor showed fast response time less than $10 \mathrm{~s}$, a good selectivity towards L-lactic acid in presence of common interfering substances such as ascorbic acid, urea, glucose, galactose, magnesium ions and calcium ions. The present biosensor based on immobilized $\mathrm{ZnO}$ nanorods with lactate oxidase sustained its stability for more than three weeks.
\end{abstract}

Keywords: zinc oxide nanorods; lactate oxidase enzyme; glutaraldehyde; potentiometric nanostructured biosensor; nanodevices

\section{Introduction}

Semiconductor metal oxide nanostructures based nanosensors have wide applications in biological, environmental and analytical chemistry sciences [1-4]. Especially one dimension nanostructures have 
promising applications in optics, optoelectronic, sensors, and actuators because these low dimensional structures exhibit attractive semiconducting, piezoelectric and pyroelectric properties, etc., as described in the literature [1,4-6]. The properties of these metal oxide nanostructures such as fast electron communication, high surface to volume ratios and electro-catalytic effectiveness make them suitable matrices for effective immobilization and the desired transducing phenomena. Moreover, electrochemical enzyme-based transducers are attractive due to their ease in detection of target analytes (enzymes and proteins), high sensitivity, low cost, simplicity and low power consumption [7]. Recently, the research trends towards nanostructures of electrochemical sensors based on various materials have increased. $\mathrm{ZnO}$ has attracted more attention among researchers for sensing bioactive substances due to its two well-known features, namely a wide band gap (3.37 eV) and high exciton binding energy $(60 \mathrm{meV})$. The structure of $\mathrm{ZnO}$ is tetragonal, in which $\mathrm{Zn}^{2+}$ and $\mathrm{O}^{2-}$ ions are alternatively arranged along the c-axis [8]. The $\mathrm{ZnO}$ material has two planes in its structure with opposite polar faces and surface relaxation energies. These nanostructures have relatively same size to those of bioactive chemical species to be sensed and are potential transducer candidates in generating electrical signals. Furthermore, $\mathrm{ZnO}$ has high ionic bonding characteristics (60\%) and sustains its stability for a long time at biological $\mathrm{pH}$ values. The nanostructures of $\mathrm{ZnO}$ show strong bonding with enzyme/ionophore membranes due to their high ionic properties. All these properties of $\mathrm{ZnO}$ enhance the efficiency of $\mathrm{ZnO}$ nanosensors with respect to output signal, catalytic effects and facilitate the ease of flow of testing substance through the sensors. The high surface to volume ratios of $\mathrm{ZnO}$ nanorods support their use as strong candidates in the area of nano-chemical sensors [9,10]. ZnO nanorods are n-type semiconductors and their electrical transport dependency is ascribed to the adsorption/ desorption properties of the chemical species [11-16]. A variety of one dimensional (1D) $\mathrm{ZnO}$ nanostructures such as nanorods, nanowires and nanotubes etc., have been synthesized by different techniques and these nanostructures have been employed in making of many nanodevices such as electric field-effect switching [17], single electron transistors [18], biological and chemical sensing [19] and luminescence [20] etc. Among these nanostructures, $\mathrm{ZnO}$ nanorods are widely used in the field of biosensing due to their high surface to volume ratios [21-24].

The isoelectric point (IEP) of lactate oxidase is 4.6 and that of $\mathrm{ZnO}$ is (9.5), this large difference in IEP between $\mathrm{ZnO}$ and lactate oxidase is evident for the $\mathrm{ZnO}$ nanomaterial to behave as a better material to immobilize low IEP proteins or DNA through strong electrostatic bonding [25-27]. Lactic acid biosensors are in high demand in clinical analysis, biotechnology, food industries and sports for the quick determination of lactic acid [28]. Amperometric biosensors commonly use enzymes including $\mathrm{NAD}^{+}$-dependent lactate dehydrogenase [29-32], hydrogen peroxidase, lactate oxidase [32-35] and flavocytochrome $b_{2}$ [37-39] for lactate determination. The purpose of all these enzymes is to provide the simple pathway for the oxidation of L-lactic acid to pyruvic acid. Lactic acid is the final product of anaerobic glycolysis; due to this lactate level in blood is essential a metabolic sign for availability and magnitude of anaerobic glycolysis [40,41]. Because of the anaerobic glycolysis these phenomena arise in the pathophysiology of hypoxia, anoxia, or ischemia. When the $\mathrm{H}^{+}$ion concentration inside the cell increases due to the above conditions, the intracellular $\mathrm{pH}$ decreases and the resulting acidosis decreases myocardial contractility as well as changes the impulse propagation. The enzyme system of many cells is also affected by $\mathrm{pH}$ changes, so for this reason the cell itself has developed plenty of ion channels, pumps, exchangers, and transporters to control the optimum intracellular $\mathrm{pH}$. The exaltation 
of lactate anion and dissemination of lactic acid seems very valuable in the mechanics of monitoring the intracellular $\mathrm{pH}$ in these circumstances $[42,43]$. Yet the cellular mechanics for controlling the intracellular $\mathrm{pH}$ are not well realized in metabolic stress situations. This is because no any particular method yet is developed to measure the extracellular lactate [44]. The determination of the amount of lactic acid in the food industry is also crucial, especially in investigating the quality of dairy products and their improvement.

The presence of amounts of lactic acid in food products has a great impact on the stability, flavor, and storage life time. Many methods had been tested for detection of lactate such as methods for chemically oxidizing lactate, spectrophotometric detection of acetaldehyde and chromatographic methods. Moreover, other techniques use the enzyme kits or biosensors involving enzymes in the detection of lactate and in doing so these techniques have replaced the chemical methods in many clinical and analytical laboratories. Many amperometric lactate biosensors have been developed for more than 20 years, in order to analyze real samples, but these amperometric biosensors have some limitations with respect to intracellular lactate determination [45-47]. On other hand the potentiometric technique has the advantage of monitoring the intracellular $\mathrm{pH}$ as well as measuring the concentration of lactate.

In the present work, we have developed for the first time an independent potentiometric biosensor based on immobilized $\mathrm{ZnO}$ nanorods with lactate oxidase. The proposed biosensor showed linear responses to lactic acid concentration, high selectivity, better sensitivity and storage stability.

\section{Experimental Section}

\subsection{Materials}

L-Lactate-oxidase from Pediococus species (E.C. 1.1.3.2, activity $40 \mathrm{U} \cdot \mathrm{mg}^{-1}$ ), L-lactic acid, glutaraldehyde (crosslinking molecule), zinc nitrate hexahydrate $\left[\mathrm{Zn}\left(\mathrm{NO}_{3}\right)_{2} \cdot 6 \mathrm{H}_{2} \mathrm{O}\right]$, hexamethylenetetramine (HMT), D-glucose, L-glucose-fructose were purchased from Sigma Aldrich (Sweden). Phosphate buffer solution (PBS) was prepared by mixing the specific concentration of each of the following chemical compounds in deionized water: potassium chloride $(\mathrm{KCl})$, sodium chloride $(\mathrm{NaCl})$, potassium hydrogen phosphate $\left(\mathrm{K}_{2} \mathrm{HPO}_{4}\right)$, sodium dihydrogenphosphate $\left(\mathrm{NaH}_{2} \mathrm{PO}_{4}\right)$, calcium chloride $\left(\mathrm{CaCl}_{2}\right)$ and the $\mathrm{pH}$ of solution was adjusted by using $100 \mathrm{mM}$ hydrochloric acid $(\mathrm{HCl})$ and $100 \mathrm{mM}$ sodium hydroxide $(\mathrm{NaOH})$; all these chemicals were also bought from Sigma Aldrich. Other than these all chemicals used were of analytical grade.

\subsection{The Fabrication of ZnO Nanorods on Gold Coated Glass}

The fabrication of $\mathrm{ZnO}$ nanorods on gold coated glass substrates was as follows: firstly glass substrates were cleaned with isopropanol in an ultrasonic bath for $15 \mathrm{~min}$, and then washed with deionized water and dried by nitrogen gas. After that glass substrates were fixed into the vacuum chamber of a Satis CR 725 evaporator instrument, for the deposition of thin film of $20 \mathrm{~nm}$ of titanium as an adhesive layer, followed by a layer of $100 \mathrm{~nm}$ thickness of gold. The growth of $\mathrm{ZnO}$ nanorods on these substrates was carried out by using the low temperature growth method (aqueous chemical growth method). The process of growing $\mathrm{ZnO}$ nanorods was as follows: first of all the gold coated 
substrates were washed with deionized water and dried by nitrogen gas, afterwards a homogeneous layer of zinc acetate was deposit on those gold coated substrates using the spin coating technique. The purpose of using the zinc acetate layer was to produce nucleation sites on the surface in order to grow well aligned $\mathrm{ZnO}$ nanorods of controlled length. The substrates with seed layer were annealed in an oven for $15 \mathrm{~min}$ at $130{ }^{\circ} \mathrm{C}$ and then affixed onto the Teflon sample holder and dipped into an equimolar solution of zinc nitrate and hexamethylenetetramine, then kept inside the oven below $100{ }^{\circ} \mathrm{C}$ for 5 to $7 \mathrm{~h}$. When the growth time was finished, these substrates were then washed with deionized water and dried by nitrogen gas. The morphological study of grown $\mathrm{ZnO}$ nanostructures was carried out by using field emission scanning electron microscopy (FESEM) and we found that well aligned and controlled in length $\mathrm{ZnO}$ nanorods were grown on the gold coated substrates, as shown in Figure 1(a).

Figure 1. (a) The (FESEM) image of $\mathrm{ZnO}$ nanorods grown on gold coated glass substrate using hydrothermal growth method. (b) The (FESEM) image of lactate oxidase immobilized $\mathrm{ZnO}$ nanorods.
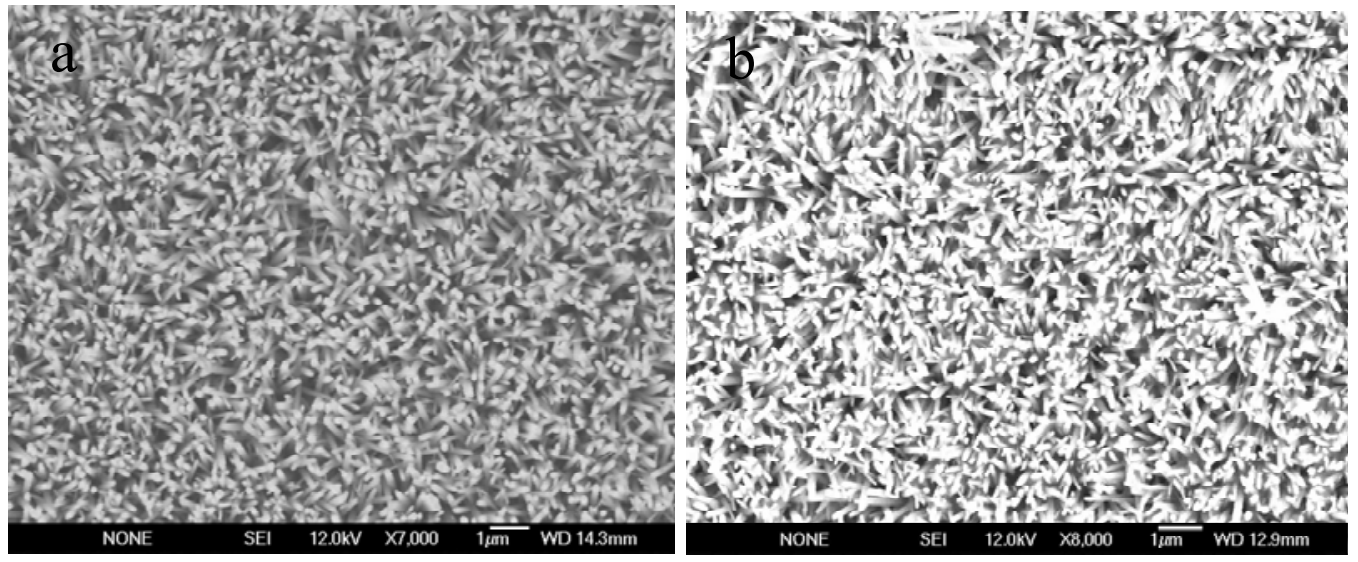

\subsection{Immobilization of $\mathrm{ZnO}$ Nanorods with Lactate Oxidase}

In this part of the experimental work, we developed five biosensor electrodes based on $\mathrm{ZnO}$ nanorods by immobilizing with lactate oxidase and crosslinking molecule (GA). We prepared 2.5\% GA solution in $0.1 \mathrm{mM}$ phosphate buffer solution (PBS) as well as lactate oxidase solution in PBS having a concentration of $2 \mathrm{mg} / \mathrm{mL}$ of enzyme. After mixing GA and enzyme solution in one bottle, we dipped the $\mathrm{ZnO}$ nanorods electrodes into it for different times in order to make ensure the saturation of the $\mathrm{ZnO}$ nanorod surface with the monolayer of enzyme. We found that after a time of $5 \mathrm{~min}$, a complete enzyme monolayer was physically adsorbed on the surface of $\mathrm{ZnO}$ nanorods as shown in Figure 1(b) and therefore we followed this immobilization timing for all experiments. Ellipsometric measurements were performed to confirm the thickness of the layer of enzyme on the surface of the $\mathrm{ZnO}$ nanorods, which was about $100 \pm 0.14 \mathrm{~nm}$. When a sensor electrode was dipped into the solution of enzyme for $5 \mathrm{~min}$, then the thickness of the enzyme monolayer was found to be $3 \mathrm{~nm}$. The potentiometric response of the present biosensor electrode based on immobilized $\mathrm{ZnO}$ nanorods was as determined as follows: the immobilized $\mathrm{ZnO}$ nanorods electrode was taken as working electrode and silver-silver $\mathrm{Ag} / \mathrm{AgCl}$ as a reference electrode and the (EMF) output response was measured using a Metrohm pH meter (model 827) and a Keithley (2400) is the time response 
measurement instrument and that was employed for the measurement of the time response. The biosensor electrodes were kept at $4{ }^{\circ} \mathrm{C}$ when not in use.

\section{Results and Discussions}

The electrochemical response (EMF) of our proposed L-lactic acid biosensor based on lactate oxidase immobilized on the surface of $\mathrm{ZnO}$ nanorods in test electrolyte solution is shown in Figure 2.

Figure 2. Calibration curve of lactate oxidase immobilized $\mathrm{ZnO}$ nanorods biosensor for L-lactic acid concentration $1 \times 10^{-4}$ to $1 \times 10^{0} \mathrm{mM}$.

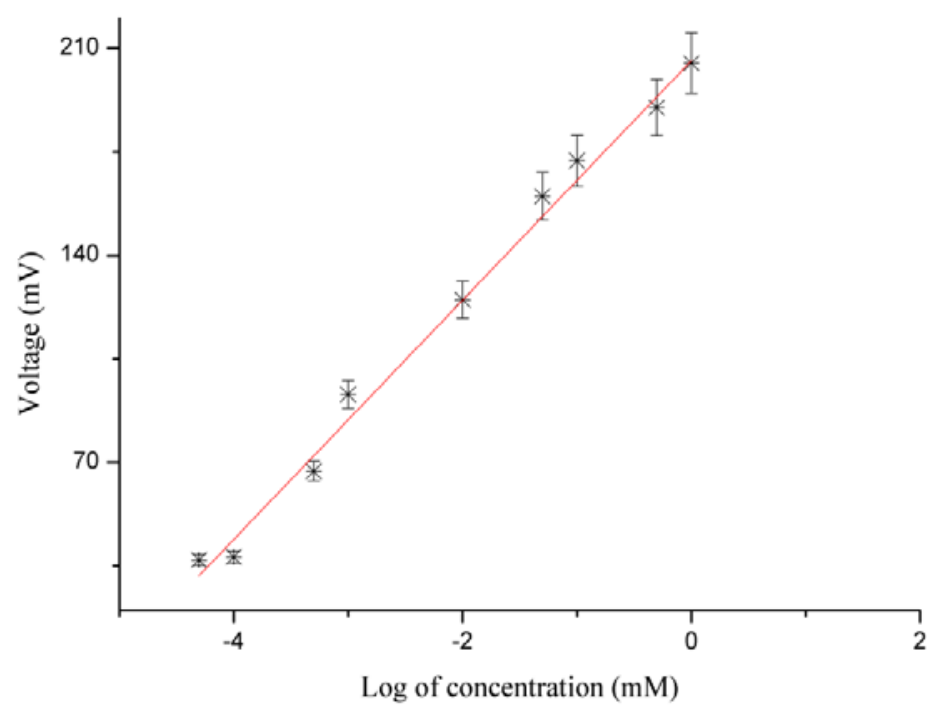

During the investigations, the output response of the biosensor was changing with the change in L-lactic acid concentration in the test solutions. Because during the oxidation of L-lactic acid in the presence of immobilized lactate oxidase, unstable pyruvic acid was produced into the solution and this pyruvic acid was spontaneously converted into pyruvate and $\mathrm{H}_{2} \mathrm{O}_{2}$, as given in Equation (1):

$$
\mathrm{L} \text { - lactic acid }+\mathrm{O}_{2} \stackrel{\mathrm{LO}_{\mathrm{x}}}{\longrightarrow} \text { Pyruvic acid }+\mathrm{H}_{2} \mathrm{O}_{2}
$$

It is the concentration of charges which is responsible for the output response of the proposed L-lactic acid biosensor. This observed potential was mainly due to the presence of charges that varied around the working electrode [48]. The output response of L-lactic acid is also dependent on the potential catalytic activity of the lactate oxidase in the presence of oxygen, with more catalytic activity resulting higher output response. When we tested the proposed biosensor electrode in different L-lactic acid concentrations ranging from $1 \times 10^{-4}$ to $1 \times 10^{0} \mathrm{mM}$, the biosensor showed a linear output response for that concentration range, as shown in Figure 2. The sensitivity of the present biosensor was observed to be around $41.33 \pm 1.58 \mathrm{mV} /$ decade.

\subsection{Effect of $\mathrm{pH}$ and Temperature on the Performance of Biosensor}

The surroundings also have a significant effect on the output response of a biosensor when it is used. For the examination of the $\mathrm{pH}$ effect on the output response of the proposed biosensor, we tested the biosensor electrode in lactic acid solution in PBS at different $\mathrm{pH}$ values ranging from $\mathrm{pH} 3$ 
to 12 . We observed that the biosensor showed a gradual increase in the response for $\mathrm{pH}$ values 6 to 9 . However, the biosensor had shown a decreasing trend for below $\mathrm{pH} 6$ and above the $\mathrm{pH}$ 9. The decreasing response of biosensor in acidic medium might be due to the slow dissolution of $\mathrm{ZnO}$ nanorods in acidic as well as in alkaline media [49, 50]. This is the reason we carried out all experiments in PBS of $\mathrm{pH} 7$, which is very close to the biological $\mathrm{pH}$ value of 7.3. Moreover it is kinetically favorable for enzyme based reactions to work at higher $\mathrm{pH}$ [51].

Figure 3. Calibration curves showing the study of EMF response with the variation of $\mathrm{pH}$ values.

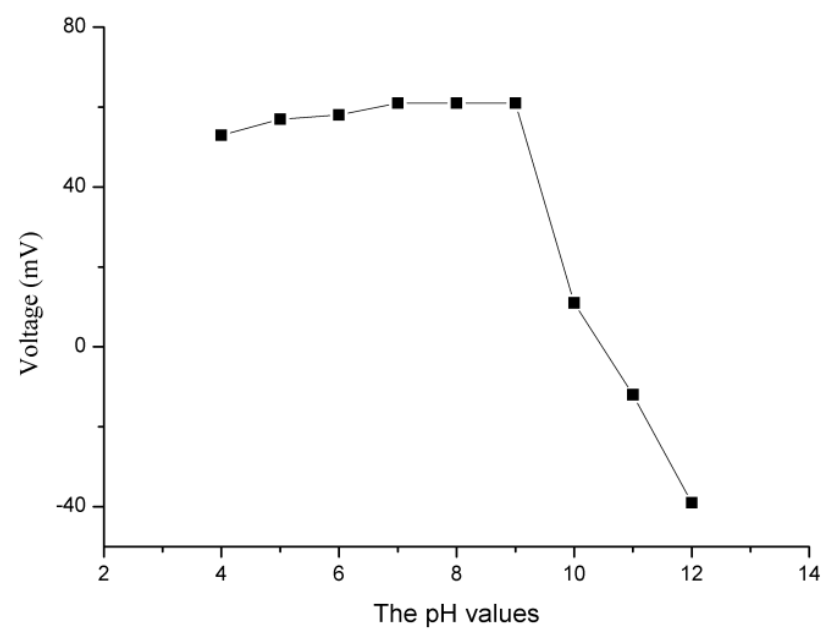

The electrochemical response (EMF) of a biosensor also depends on the ambient temperature. For this purpose, we performed the controlled experiments at temperatures ranging from $23{ }^{\circ} \mathrm{C}$ to $75{ }^{\circ} \mathrm{C}$. During the investigation, we observed that the present biosensor worked very well at room temperature rather than at high temperature, as shown in Figure 4. It has been reported in the literature that the lactate oxidase has its optimum activity at $30^{\circ} \mathrm{C}$ [52], but the response of the present biosensor was found higher at room temperature due to possibly enhanced activity of the enzyme on the surface of $\mathrm{ZnO}$ nanorods and might be the $\mathrm{ZnO}$ behaved as a promoter for lactate oxidase.

Figure 4. Calibration curves showing the study of EMF response with the change in temperature values.

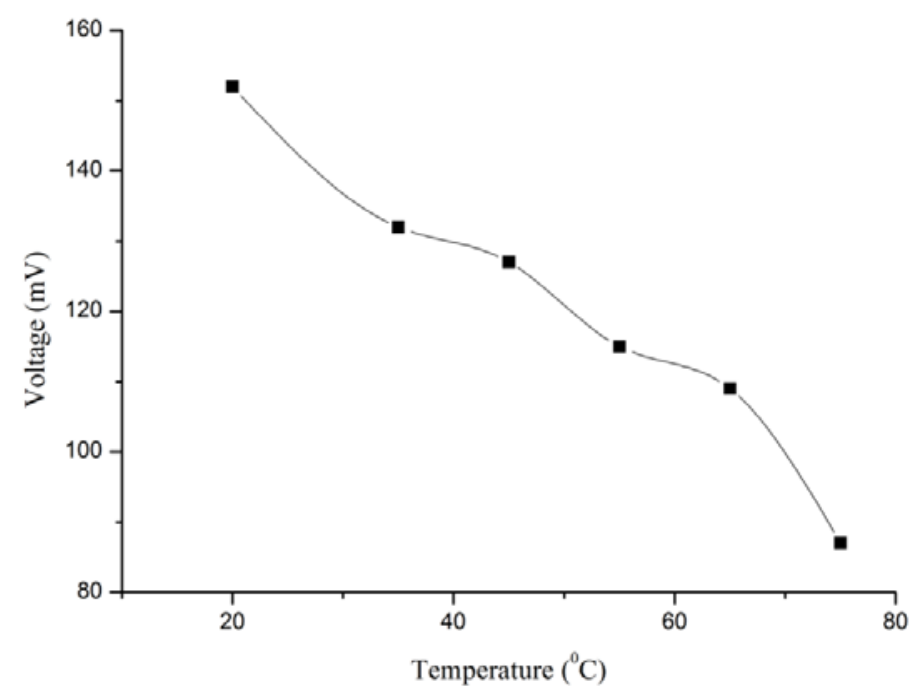




\subsection{Study of Common Interfering Substances on the Output Response of L-Lactic Acid and Response Time}

Selectivity of the biosensor is one of the fundamental parameters for the performance evaluation and it was evaluated in the test electrolytic solution in the presence of other interfering species. During this experimental part, we studied the most commonly interfering species such as ascorbic acid, L-cysteine, glucose, urea, magnesium ions $\left(\mathrm{Mg}^{2+}\right)$, and calcium ions $\left(\mathrm{Ca}^{2+}\right)$, using a separation method for observing the biosensor selectivity.

The calculated selectivity coefficient $(\mathrm{K})$ values for these interfering substances are given in Table 1 . It has been seen already that ascorbic acid has a significant effect on the response of lactic acid biosensors [53], but the present biosensor has shown no response to ascorbic acid. We used the $1 \times 10^{-3} \mathrm{mM}$ concentration range of each interfering substance. It has been observed that the proposed biosensor has the ability to work very well against the common interfering substances and therefore can be applied to determine the L-lactic acid in biological fluids, food, sport and clinical samples. Beside the selectivity, we examined the response time of the biosensor for all the detectable concentration ranges. It was observed that biosensor showed fast response times for higher concentrations and slower response times for low concentrations. Thus, the biosensor has shown a response time less than $10 \mathrm{~s}$ for all concentrations ranging from $0.01 \mathrm{mM}$ to $1 \mathrm{mM}$, as shown in Figure 5 .

Table 1. Selectivity coefficient in $10^{-3} \mathrm{mM}$.

\begin{tabular}{cc}
\hline Interference (B) & Log $\mathbf{K}_{\text {lactic acid, B }}^{\text {pot }}$ \\
\hline $\mathbf{M g}^{2+}$ & 0.5323 \\
$\mathbf{C a}^{2+}$ & 0.7259 \\
Glucose & 1.0404 \\
Urea & 1.3791 \\
L-cysteine & 1.1856 \\
Galactose & 1.5485 \\
Vitamin C & 1.7421 \\
\hline
\end{tabular}

Figure 5. The response time of the proposed biosensor.

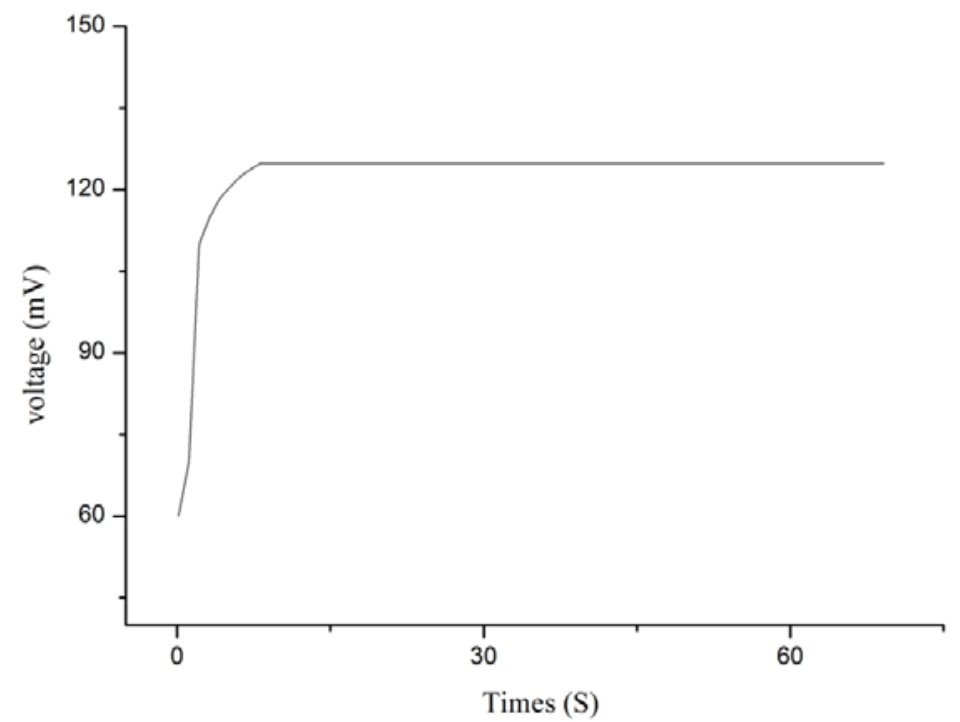




\subsection{Study of Life Time of Biosensor and Reproducibility}

This study demonstrated that the biosensor has a lifetime stability of more than three weeks and also good reproducibility. We tested the lactic acid biosensor based on lactate oxidase immobilized on $\mathrm{ZnO}$ nanorods for three consecutive weeks and found that the biosensor maintained the detection range of lactic acid concentrations but in the third week a small decrease in sensitivity was observed as shown in Table 2. This might be due to the separation of lactate oxidase from the crosslinking molecules (GA).

Table 2. The life time of electrode.

\begin{tabular}{ccc}
\hline Number of days & Slope $(\mathbf{m V} /$ decade) & Linear range $(\mathbf{m M})$ \\
\hline $\mathbf{1}$ & $41.33 \pm 1.58$ & $1 \times 10^{-4}-1 \times 10^{0}$ \\
$\mathbf{7}$ & $42.57 \pm 1.82$ & $1 \times 10^{-4}-1 \times 10^{0}$ \\
$\mathbf{1 4}$ & $41.39 \pm 1.72$ & $1 \times 10^{-4}-1 \times 10^{0}$ \\
$\mathbf{2 1}$ & $40.80 \pm 1.84$ & $1 \times 10^{-4}-1 \times 10^{0}$ \\
\hline
\end{tabular}

\subsection{Comparison of Present Proposed Biosensor with Already Existing L-Lactic Acid Sensors}

Table 3 shows the results of the proposed L-lactic acid compared with the already existing L-lactic acid sensors. The proposed sensor based on the lactate oxidase immobilized on the $\mathrm{ZnO}$ nanorods has shown a low detection limit for the lactic acid, fast response time, good storage stability, better sensitivity, and high selectivity against interfering substances. These all advantageous features prove that the proposed biosensor based on the $\mathrm{ZnO}$ nanorods has the ability to firmly bind enzyme molecules on its surface and exhibited a selective determination of the target analyte.

Table 3. Comparison of lactose biosensor with the previous work.

\begin{tabular}{ccccccc}
\hline No. & $\begin{array}{c}\text { Slope } \\
(\mathbf{m V} / \text { decade) }\end{array}$ & $\begin{array}{c}\text { Times } \\
\text { respond }(\mathbf{s})\end{array}$ & $\begin{array}{c}\text { Detection } \\
\text { Limit }(\mathbf{m M})\end{array}$ & $\begin{array}{c}\text { Linear } \\
\text { range }(\mathbf{m M})\end{array}$ & Lifetimes & Reference \\
\hline $\mathbf{1}$ & - & 90 & - & $5.0 \times 10^{-2}-25 \times 10^{-2}$ & 2 weeks & {$[29]$} \\
$\mathbf{2}$ & - & 40 & $1.0 \times 10^{-1}$ & $5.0 \times 10^{-1}-6.0 \times 10^{0}$ & 2 weeks & {$[30]$} \\
$\mathbf{3}$ & $24 \pm 2$ & 15 & $1.0 \times 10^{-1}$ & $1.0 \times 10^{-1}-1.0 \times 10^{1}$ & - & {$[31]$} \\
$\mathbf{4}$ & - & 30 & $1.0 \times 10^{0}$ & $1.0 \times 10^{0}-15 \times 10^{0}$ & - & {$[32]$} \\
$\mathbf{5}$ & - & - & $1.0 \times 10^{-3}$ & $2.0 \times 10^{-4}-8.0 \times 10^{-3}$ & 2 weeks & {$[34]$} \\
$\mathbf{6}$ & - & - & - & $\mathrm{Up} \mathrm{to} 1.6 \times 10^{1}$ & 15 days & {$[35]$} \\
$\mathbf{7}$ & - & $30-42$ & $1.0 \times 10^{-2}$ & $1.0 \times 10^{-2}-1.0 \times 10^{0}$ & $3-9$ days & {$[37]$} \\
$\mathbf{8}$ & - & - & $1.0 \times 10^{-3}$ & $1.0 \times 10^{-3}-1.0 \times 10^{1}$ & 5 weeks & {$[38]$} \\
$\mathbf{9}$ & $41 \pm 2$ & $\approx 10$ & $1.0 \times 10^{-4}$ & $1.0 \times 10^{-4}-1.0 \times 10^{0}$ & More than 3 weeks & this work \\
\hline
\end{tabular}

\section{Conclusions}

In the present work, we have successfully demonstrated the potentiometric determination of L-lactic acid using $\mathrm{ZnO}$ nanorods immobilized with lactate oxidase in conjunction with (GA) crosslinking molecules by using a physical adsorption method. The proposed biosensor showed good stability, linearity, sensitivity, and selectivity when it was exposed to L-lactic acid test solutions. Based on all 
obtained results, the proposed sensor can be applicable to detect L-lactic acid in drugs, food and other biological samples.

\section{References}

1. Wang, J. Nanomaterial-based electrochemical biosensors. Analyst 2005, 130, 421-426.

2. Luo, X.; Morrin, A.; Killard, A.J.; Smyth, M.R. Application of nanoparticles in electrochemical sensors and biosensors. Electroanalysis 2006, 18, 319-326.

3. Valentini, F.; Palleschi, G. Nanomaterials and analytical chemistry. Anal. Lett. 2008, 41, 479-520.

4. Chopra, N.; Gavalas, V.G.; Bachas, L.G.; Hinds, B.J.; Bachas, L.G. Functional one dimensional nanomaterials: Applications in nanoscale biosensors. Anal. Lett. 2007, 40, 2067-2096.

5. Kerman, K.; Saito, M.; Amamura, S.Y.; Takmura, Y.; Tamiya, E. Nanomaterial-based electrochemical biosensors for medical applications. Trends Anal. Chem. 2008, 27, 585-592.

6. Chow, D.C.; Johannes, M.S.; Lee, W.K.; Clark, R.L.; Zauscher, S.; Chilkoti, A. Nanofabrication with biomolecules. Mater. Today 2005, 8, 30-39.

7. Anees, A.; Ansari, M.; Alhoshan, M.S.; Alsalhi, A.S. Aldwayyan Nanostructured Metal Oxides Based Enzymatic Electrochemical Biosensors; InTech: Rijeka, Croatia, 2010; pp. 23-46.

8. Wang, Z.L.; Kong, X.Y.; Ding, Y.; Gao, P.; Hughes, W.L.; Yang, R.; Zhang, Y. Semiconducting and piezoelectric oxide nanostructures induced by polar surface. Adv. Funct. Mater. 2004, 14, 943-956.

9. Tien, L.C.; Sadik, P.W.; Norton, D.P.; Voss, L.F.; Pearton, S.J.; Wang, H.T.; Kang, B.S.; Ren, F.; Jun, J.; Lin, J. Hydrogen sensing at room temperature with Pt-coated $\mathrm{ZnO}$ thin films and nanorods. Appl. Phys. Lett. 2005, 87, 222106-222108.

10. Hsueh, T.J.; Chang, S.J.; Hsu, C.L.; Lin, Y.R.; Chen, I.C. Highly sensitive ZnO nanowire ethanol sensor with Pd adsorption. Appl. Phys. Lett. 2007, doi: 10.1063/1.2757605.

11. Li, Q.H.; Gao, T.; Wang, Y.G.; Wang, T.H. Adsorption and desorption of oxygen probed from $\mathrm{ZnO}$ nanowire films by photocurrent measurements. Appl. Phys. Lett. 2005, 86, 123117-123119.

12. Hung, X.J.; Choi, Y.K. Chemical sensors based on nanostructured materials. Sens. Actuat. B 2007, 122, 659-671.

13. Li, C.C.; Du, Z.F.; Li, L.M.; Yu, H.C.; Wan, Q.; Wang, T.H. Surface-depletion controlled gas sensing of $\mathrm{ZnO}$ nanorods grown at room temperature. Appl. Phys. Lett. 2007, doi: 10.1063/1.2752541.

14. Ghosh, R.; Dutta, M.; Basak, D. Self-seeded growth and ultraviolet photoresponse properties of ZnO nanowire arrays. Appl. Phys. Lett. 2007, doi: 10.1063/1.2771533.

15. Qiu, Y.F.; Yang, S.H. ZnO nanotetrapods: Controlled vapor-phase synthesis and application for humidity sensing. Adv. Funct. Mater. 2007, 17, 1345-1352.

16. Park, J.Y.; Song, D.E.; Kim, S.S. An approach to fabricating chemical sensors based on $\mathrm{ZnO}$ nanorod arrays. Nanotechnology 2008, 19, 105503-105508.

17. Kim, G.T.; Muster, J.; Krstic, V.; Park, J.G.; Park, Y.W.; Roth, S.; Burghard, M. Field-effect transistor made of individual $\mathrm{V}_{2} \mathrm{O}_{5}$ nanofibers. Appl. Phys. Lett. 2000, 76, 1875-1877.

18. Stone, N.J.; Ahmed, H. Silicon single electron memory cell. Appl. Phys. Lett.1998, 73, 2134-2136.

19. Cui, Y.; Wei, Q.; Park, H.; Lieber, C.M. Nanowire nanosensors for highly sensitive and selective detection of biological and chemical species. Science 2001, 293, 1289-1292. 
20. Huang, M.H.; Mao, S.; Feick, H.; Yan, H.; Wu, Y.; Kind, H.; Weber, E.; Russo, R.; Yang, P. Room-temperature ultraviolet nanowire nanolasers. Science 2001, 292, 1897-1899.

21. Wei, A.; Sun, X.W.; Wang, J.X.; Lei, Y.; Cai, X.P.; Li, C.M.; Dong, Z.L.; Huang, W. Enzymatic glucose biosensor based on $\mathrm{ZnO}$ nanorod array grown by hydrothermal decomposition. Appl. Phys. Lett. 2006, doi: 10.1063/1.2356307.

22. Ibupoto, Z.H.; Ali, S.M.U.; Khun, K.; Chey, C.O.; Nur, O.; Willander, M. ZnO nanorods based enzymatic biosensor for selective determination of penicillin. Biosensors 2011, 1, 153-163.

23. Zhao, J.; Zhi, J.; Zhou, Y.; Yan, W. A tyrosinase biosensor based on ZnO nanorod clusters/nanocrystalline diamond electrodes for biosensing of phenolic compounds. Anal. Sci. 2009, 25, 1083-1088.

24. Zhanga, F.; Wanga, X.; Aia, S.; Suna, Z.; Wana, Q.; Zhub, Z.; Xiana, Y.; Jina, L.; Yamamotoc, K. Immobilization of uricase on $\mathrm{ZnO}$ nanorods for a reagentless uric acid biosensor. Anal. Chim. Acta 2004, 519, 155-160.

25. Ali, S.M.U.; Nur, O.; Willander, M.; Danielsson, B. Glucose detection with commercial MOFET using $\mathrm{ZnO}$ nanowires extended GATE. IEEE Trans. Nanotechnol. 2009, 8, 678-683.

26. Ali, S.M.U.; Nur, O.; Willander, M.; Danielsson, B. A fast and sensitive potentiometric glucose microsensor based on glucose oxidase coated $\mathrm{ZnO}$ nanowires grown on a thin silver wire. Sens. Actuat. B 2010, 145, 869-874.

27. Ali, S.M.U.; Alvi, N.H.; Ibupoto, Z.; Nur, O.; Willander, M.; Danielsson, B. Selective potentiometric determination of uric acid with uricase immobilized on $\mathrm{ZnO}$ nanowires. Sens. Actuat. B 2010, 2, 241-247.

28. Nikolaus, N.; Strehlitz, B. Amperometric lactate biosensors and their application in (sports) medicine, for life quality and wellbeing. Microchem. Acta 2008, 160, 15-55.

29. Gerard, M.; Ramanathan, K.; Chaubey, A.; Malhotra, B.D. Immobilization of lactate dehydrogenase on electrochemically prepared polyaniline films. Electroanalysis 1999, 11, $450-452$.

30. Chaubey, A.; Gerard, M.; Singhal, R.; Singh, V.S.; Malhotra, B.D. Immobilization of lactate dehydrogenase on electrochemically prepared polypyrrole-polyvinylsulfonate composite films for application to lactate biosensors. Electrochim. Acta 2000, 46, 723-729.

31. Zayats, M.; Kharitonov, A.B.; Katz, E.; Buckmann, A.F.; Wilner, I. An integrated NAD ${ }^{+}$-dependent enzyme-functionalized field effect transistor (ENFET) system: Development of a lactate biosensor. Biosens. Bioelectron. 2000, 15, 671-680.

32. Leonida, M.D.; Starczynowski, D.T.; Waldman, R.; Aurian-Blajeni, B. Polymeric FAD used as enzyme-friendly mediator in lactate detection. Anal. Bioanal. Chem. 2003, 376, 832-837.

33. Spohn, U.; Narasaiah, D.; Gorton, L. The influence of the carbon paste composition on the performance of an amperometric bienzyme sensor for L-lactate. Electroanalysis 1996, 8, 507-514.

34. Garjonyte, R.; Y.; Yigzaw, Meskys, R.; Malinauskas, A.; Gorton, L. Prussian blue- and lactate oxidase-based biosensor for lactic acid. Sens. Actuat. B 2001, 87, 33-38.

35. Hirano, K.; Yamato, H.; Kurimoto, K.; Ohwa, M. Design of novel electron transfer mediators based on indophenol derivatives for lactate sensor. Biosens. Bioelectron. 2002, 17, 315-322.

36. Kulys, J.J.; Svirmickas, G.J.S. Reagentless lactate sensor based on cytochrome $b_{2}$. Anal. Chem. Acta 1980, 117, 115-120. 
37. Staskeviciene, S.L.; Cenas, N.K.; Kulys, J.J. Reagentless lactate electrodes based on electro catalytic oxidation of flavocytochrome $b_{2}$. Anal. Chem. Acta 1991, 243, 167-171.

38. Amine, A.; Deni, J.; Kaufmann, J.M. Amperometric biosensor based on carbon paste mixed with enzyme, lipid and cytochrome c. Bioelectrochem. Bioenerg. 1994, 34, 123-128.

39. Smutok, O.; Gayda, G.; Gonchar, M.; Schuhmann, W. A novel L-lactate-selective biosensor based on flavocytochrome $b_{2}$ from methylotrophic yeast Hansenula polymorpha. Biosens. Bioelectron. 2005, 20, 1285-1290.

40. Neely, J.R.; Whitmer, J.T.; Rovetto, M.J. Effect of coronary flow on glycolytic flux and intracellular $\mathrm{pH}$ in isolated rat hearts. Circ. Res. 1975, 37, 733-741.

41. Kobayashi, K.; Neely, J.R. Control of maximum rates of glycolysis in rat cardiac muscle. Circ. Res. 1979, 44, 166-175.

42. Reimer, K.A.; Jennings, R.B. The Heart and Cardiovascular System, 2nd ed.; Raven Press Ltd.: New York, NY, USA, 1992; pp. 1875-1973.

43. Gettes, L.S.; Cascio, W.E. Heart and Cardiovascular System Scientific Foundations, 2nd ed.; Fozzard, H., Ed.; Raven Press: New York, NY, USA, 1992; pp. 2021-2054.

44. Marzouk, S.A.M.; Cosofret, V.V.; Buck, R.P.; Yang, H.; Cascio, W.E.; Hassan, S.S.M. A conducting salt-based amperometric biosensor for measurement of extracellular lactate accumulation in ischemic myocardium. Anal. Chem. 1997, 69, 2646-2652.

45. Hu, Y.; Zhang, Y.; Wilson, G.S. A needle-type enzyme-based lactate sensor for in vivo monitoring. Anal. Chim. Acta 1993, 281, 503-511.

46. Zhang, Y.; Wilson, G.S. In vitro and in vivo evaluation of oxygen effects on a glucose oxidase based implantable glucose sensor. Anal. Chim. Acta 1993, 281, 513-520.

47. Hu, Y.; Mitchell, K.M.; Albahadily, F.N.; Michaelis, E.K.; Wilson, G.S. Direct measurement of glutamate release in the brain using a dual enzyme-based electrochemical sensor. Brain Res. 1994, $659,117-125$.

48. Al-Hilli, S.M.; Al-Mofarji, R.T.; Klason, P.; Willander, M. Zinc oxide nanorods grown on two-dimensional macroporous periodic structures and plane $\mathrm{Si}$ as a $\mathrm{pH}$ sensor. J. Appl. Phys. 2008, 103, 014302:1-014302:7.

49. Fulati, A.; Usman Ali, S.M.; Riaz, M.; Amin, G.; Nur, O.; Willander, M. Miniaturized pH sensors based on zinc oxide nanotubes/nanorods. Sensors 2009, 9, 8911-8923.

50. Demianets, L.N.; Kostomarov, D.V.; Kuz'mina, I.P.; Pushko, S.V. Mechanism of growth of ZnO single crystals from hydrothermal alkali solutions. Crystallogr. Rep. 2002, 47, S86-S98.

51. Schwert, G.W.; Miller B.R.; Peanasky, R.J. Lactic dehydrogenase X. A re-evaluation of the effects of $\mathrm{pH}$ upon the kinetics of the reaction. J. Biol. Chem. 1967, 242, 3245-3252.

52. Haesbe, K.; Hikima, S.; Yoshida, H. Differential pulse polarographic determination of L-lactate with a soluble enzyme preparation. Fresenius J. Anal. Chem. 1990, 336, 586-588.

53. Sayed, A.M.; Marzouk, V.; Cosofret, V.; Richard, P.B.; Hua, Y.; Wayne, E.C.; Saad, S.M.H. A conducting salt-based amperometric biosensor for measurement of extracellular lactate accumulation in ischemic myocardium. Anal. Chem. 1997, 69, 2646-2652.

(C) 2012 by the authors; licensee MDPI, Basel, Switzerland. This article is an open access article distributed under the terms and conditions of the Creative Commons Attribution license (http://creativecommons.org/licenses/by/3.0/). 